\title{
Genotyping spring viraemia of carp virus and other piscine vesiculo-like viruses using reverse hybridisation
}

\author{
A. M. Sheppard, R.-M. Le Deuff, P. D. Martin, G. Woolford, K. Way, D. M. Stone* \\ Centre for Environment, Fisheries and Aquaculture Science, Weymouth Laboratory, Barrack Road, Weymouth, \\ Dorset DT4 8UB, UK
}

\begin{abstract}
A simple nylon membrane-based DNA macroarray was developed to genotype spring viraemia of carp virus (SVCV) and related viruses. Twenty-six viruses were genotyped using the array, and the results were confirmed by phylogenetic analysis of a $426 \mathrm{bp}$ partial glycoprotein gene sequence. The array was not only capable of discriminating between the 4 main genogroups of cyprinid vesiculo-type viruses described previously, but also accurately sub-type the SVC viruses assigned to Genogroup I. The assay offers a practical solution for diagnostic laboratories that currently lack a sequencing capability to confirm the nature of PCR products generated in suspected SVCV cases.
\end{abstract}

KEY WORDS: Rhabdovirus - Spring viraemia of carp virus · SVCV · Vesiculovirus · Genotyping · Reverse hybridisation

\section{INTRODUCTION}

Spring viraemia of carp virus (SVCV) is a severe haemorrhagic disease of cyprinids requiring report to the Office International des Epizooties (OIE) and under UK fish health regulations. Antigenically related viruses, which are currently not subject to report, have been isolated from a number of cyprinid species traditionally thought to be susceptible to SVCV, including grass carp Ctenopharyngodon idella, carucian carp Carassius carassius, tench Tinca tinca, roach Rutilus rutilus, and also from common bream Abramis brama and pike Esox lucius. Phylogenetic analysis of a $550 \mathrm{bp}$ region of the glycoprotein gene has led to the grouping of SVCV and related vesiculo-type viruses into 4 genogroups (Stone et al. 2003). Genogroup I, the Rhabdovirus carpio group, comprises all of the isolates classified by serology as SVCV. This group can be further divided into 4 subgroups correlating with their geographical origins: Asian (Subgroup a), eastern European (Subgroups b and c) and western European (Subgroup d). Genogroup II, the grass carp rhabdovirus (GrcRV) group comprises a single isolate, previously identified as pike fry rhabdovirus (PFRV). Genogroup III, the pike fry rhabdovirus group comprises the original PFRV reference isolate (de Kinkelin et al. 1973). Genogroup IV the tench rhabdovirus (TenRV) group comprises non-SVCV/non-PFRV isolates (including some previously identified as PFRV by serology).

It is often difficult to distinguish between SVCV and related viruses using the serological assays currently recommended by the OIE (Ahne et al. 1998, Rowley et al. 2001, Way et al. 2003, Dixon \& Longshaw 2005). This raises concerns with regards to the accurate identification of SVCV and the reliability of some historical SVC diagnoses. It is important, therefore, to develop accurate methods to distinguish between SVCV and other fish vesiculo-type rhabdoviruses. 
A number of molecular diagnostic methods have been described as alternatives to antiserum-based assays. In 1998, Ahne et al. described a ribonuclease protection assay based on SVCV glycoprotein (G)gene-specific probes. Although it is able to distinguish between SVCV and related viruses, the method is labour intensive, and, since it also uses ${ }^{32} \mathrm{P}$-labelled reagents, it is not ideally suited for use in a routine diagnostic setting. The reverse transcription polymerase chain reaction (RT-PCR) method described by Koutná et al. (2003) uses non-degenerative primers, and there is therefore a risk that the assay will fail to detect all of the isolates in what is now known to be a genetically diverse group of viruses showing up to $17.3 \%$ nucleotide sequence divergence (Stone et al. 2003). This scenario has previously been observed with nodavirus-specific primers that failed to detect a Mediterranean isolate of the same virus despite their ability to detect isolates from a wide range of fish species from different geographical origins (Thiery et al. 1999). Similarly, the matrix protein and G-genespecific RT-PCR of Oreshkova et al. (1999) uses nondegenerative primers. In contrast, Stone et al. (2003) used highly degenerative primer sets that generate amplicons for Genogroups I and IV and when confirming by sequencing that the product was viral in origin they were able to discriminate between products generated by viruses from Genogroups I and IV. This approach has recently been adopted by the OIE as a confirmatory method for the presence of SVCV in cell culture supernatant (www.oie.int/eng/normes/fmanual/ a_00021.htm).

In the current study we describe an alternative method to discriminate between amplicons generated using the OIE recommended method, for laboratories in which sequence analysis is currently unavailable. We have developed a simple reverse hybridisation technique, or macroarray assay in which digoxigenin (DIG)-labelled amplicons are captured by genogroupspecific probes immobilised on a nylon membrane. The capture is then revealed using a 5-bromo-4chloro-3-indolyl phosphate (BCIP)/nitro blue tetrazolium (NBT) alkaline phosphatase (AP) system. This approach cannot only discriminate between SVCV and TenRV, the 2 viruses detected using the SVCV primers described by Stone et al. (2003), but can also be used to assign SVCV isolates to the appropriate SVCV subgroups (a to d).

\section{MATERIALS AND METHODS}

A 714 bp segment corresponding to nucleotides 265 to 978 of the G gene were amplified by RT-PCR using the primer pair SVCV R2 5'-AGATGGTATGGACCC-
CAATACATHACNCAY-3' and SVCV F1 5'-TCTTGGAGCCAAATAGCTCARRTC-3' (Stone et al. 2003).

A simple RNA extraction and RT-PCR amplification method has been described previously (Strømmen \& Stone 1998). Total RNA was extracted from $100 \mu \mathrm{l}$ tissue culture supernatant using Trizol reagent (Invitrogen), and the pellet was resuspended in $40 \mu \mathrm{l}$ DNase/ Rnase-free water. Reverse transcription was performed at $37^{\circ} \mathrm{C}$ for $1 \mathrm{~h}$ in a $20 \mu \mathrm{l}$ volume consisting of $1 \times$ Moloney murine leukemia virus reverse transcriptase (M-MLV RT) reaction buffer (50 mM Tris [pH 8.3], $75 \mathrm{mM} \mathrm{KCL}, 10 \mathrm{mM}$ dithiothreitol [DTT], $3 \mathrm{mM} \mathrm{MgCl}_{2}$ ) containing $1.0 \mathrm{mM}$ dNTP mix , 100 pmol SVCV R2, $20 \mathrm{U}$ M-MLV RT (Promega) and $4 \mu \mathrm{l}$ of the total RNA extracted as above. PCR was performed in a $50 \mu \mathrm{l}$ reaction volume consisting of $1 \times$ Go Taq Flexi PCR buffer, $2.5 \mathrm{mM} \mathrm{MgCl} 2,1.0 \mathrm{mM}$ dNTPs mix, 50 pmol each of the SVCV R2 and SVCV F1 primers, $2.5 \mathrm{U}$ of Go Taq polymerase (Promega) and $2.5 \mu \mathrm{l}$ of the reverse transcription reaction. The $50 \mu \mathrm{l}$ reaction was overlaid with mineral oil and subjected to 35 cycles of: $1 \mathrm{~min}$ at $95^{\circ} \mathrm{C}$, $1 \mathrm{~min}$ at $55^{\circ} \mathrm{C}$ and $1 \mathrm{~min}$ at $72^{\circ} \mathrm{C}$, followed by a final extension step of $10 \mathrm{~min}$ at $72^{\circ} \mathrm{C}$.

It is at this stage that the product would traditionally be sequenced to discriminate between the 4 subgroups of SVCV and TenRV. To discriminate by reverse hybridisation, the DIG-labelling PCR was performed in a $50 \mu \mathrm{l}$ reaction containing $2.5 \mu \mathrm{l}$ of the first-round product, 100 pmol of the primers SVCV R4 5'CTGGGGTTTCCNCCTCAAAGYTGY-3' and SVCV F1, 2.5 U of GoTaq DNA polymerase (Promega) and $5 \mu \mathrm{l}$ of PCR DIG-labelling mix (Roche). The $50 \mu \mathrm{l}$ reaction was overlaid with mineral oil and subjected to 35 cycles of: $1 \mathrm{~min}$ at $95^{\circ} \mathrm{C}, 1 \mathrm{~min}$ at $55^{\circ} \mathrm{C}$ and $1 \mathrm{~min}$ at $72^{\circ} \mathrm{C}$, followed by a final extension step of $10 \mathrm{~min}$ at $72^{\circ} \mathrm{C}$. To generate DIG-labelled products for representatives of Genogroups II and III, the modified R4 primer described by Stone et al. (2003) was used.

Genotype and sub-group-specific oligonucleotides (100 to 112 nucleotides in length) were used as capture probes (Table 1). The regions chosen for probe design were those that were highly conserved within the genogroup (>95\% nucleotide identity), but showed significant nucleotide sequence divergence when compared to the other genogroups $(<91 \%$ nucleotide identity). The capture probes $(1 \mu \mathrm{g})$ were denatured in $200 \mu \mathrm{l}$ denaturing solution $(0.4 \mathrm{M}$ $\mathrm{NaOH}, 10 \mathrm{mM}$ EDTA) by boiling for 5 min before being dotted onto a hybond-N+ nylon membrane (GE Healthcare) using a slot blot apparatus. The membrane was fixed by baking in a microwave $(750 \mathrm{~W})$ at full power for $1 \mathrm{~min}$ and then placed in a $50 \mathrm{ml}$ hybridisation tube containing $5 \mathrm{ml}$ of hybridisation buffer $(10 \times$ Denhart's solution, $2 \times$ SSC, $1 \%$ SDS, $0.1 \mathrm{mg} \mathrm{ml}^{-1}$ salmon testes DNA) and incubated at 
Table 1. Oligonucleotide capture probes. SVCV: spring viraemia of carp virus; GrcRV: grass carp rhabdovirus; PFRV: pike fry rhabdovirus; TenRV: tench rhabdovirus

\begin{tabular}{|c|c|c|}
\hline Probe & Sequence & $\begin{array}{c}\text { Length } \\
\text { (nucleotides) }\end{array}$ \\
\hline SVCV Ia & $\begin{array}{l}\text { TGAGACCGTGCAGCATGAATGTGAAAAGCACATAGAGGAAGTTGAAGGAATTATGTAC } \\
\text { GGGAATGCTCCGAGAGGGGATGCAATATATATTAACAACTTTATTATAGATAAA }\end{array}$ & 112 \\
\hline SVCV Ib & $\begin{array}{l}\text { CGCAAGAGGAGACTGGGTAGAGAAGACAGCTGGAACATTAACAACGATTTATAACAAT } \\
\text { GTACCTAGATGTGCTGATGGGACGTTGATCTCCGGTCACCGAC }\end{array}$ & 101 \\
\hline SVCV IC & $\begin{array}{l}\text { TGCAAGAGGAGACTGGGTAGAGAAAACAGCTGGAGCATTGACGACTATTTATAACAAT } \\
\text { ATACCTAGATGTGTTGATGGAACTTTGGTCACCGGTCACCGAC }\end{array}$ & 101 \\
\hline SVCV Id & $\begin{array}{l}\text { GCGAGAGGAGACTGGGTAGAGAAAACAGCCGGAACATTAACAACGATTCATGACAAT } \\
\text { GTGCCTAAATGTGTTGATGGAACGTTGGTCTCCGGTCACCGCCCC }\end{array}$ & 102 \\
\hline GrcRV & $\begin{array}{l}\text { ATAGAGGAGTTGACAGGGGTTATGTATGGGAACGTCCTCAGGGGGGACAACTTGTATG } \\
\text { TGAATAACTTCATGATAGATCAGCATCACGGAGTCTACAAGTT }\end{array}$ & 101 \\
\hline PFRV & $\begin{array}{l}\text { ATCGAGGAAACAACAGGGACCATGTATGGAAATGCTCTGAGGGGGGATAATCTGTATG } \\
\text { TAAACAATTTTATCATTGACGATCATCATAGAGTCTACAAGTT }\end{array}$ & 101 \\
\hline TenRV & $\begin{array}{l}\text { CATGTCTTAAAAGAGGAATGTGACCAGCACATTGAGGAGACAACAGGAATCATGTATG } \\
\text { GAAATGTCTTGAGAGGTGACAACCTGTACGTGAATAATTTTAT }\end{array}$ & 101 \\
\hline
\end{tabular}

$50^{\circ} \mathrm{C}$ for $1 \mathrm{~h}$. The prehybridisation step helps to minimise background staining. All hybridisation, washing and detection steps were then performed in the same tube. The DIG-labelled PCR products were denatured at $95^{\circ} \mathrm{C}$ for $5 \mathrm{~min}$ and added to the hybridisation buffer. Membranes were then hybridised at $50^{\circ} \mathrm{C}$ for $3 \mathrm{~h}$ followed by 4 post-hybridisation washes performed with $1.0 \times \mathrm{SSC}$ and $0.1 \% \mathrm{SDS}$ at $65^{\circ} \mathrm{C}$ for $20 \mathrm{~min}$ each. These washes are essential to minimise cross-hybridisation. The membranes were washed briefly in Tris-buffered saline (Sigma) and then incubated in $5 \mathrm{ml}$ Anti-DIG AP solution $(1 \times$ Trisbuffered saline, $0.1 \%$ bovine serum albumin, $0.05 \%$ Tween 20) containing $150 \mu \mathrm{U} \mathrm{ml}^{-1}$ Anti-Dig-AP $\mathrm{Fb}$ fragments (Roche).

The hybridised product was then detected using an alkaline phosphatase conjugate substrate kit (BIORAD).

\section{RESULTS AND DISCUSSION}

To validate the reverse hybridisation system a total of 25 vesiculo-type isolates were used in this study (Table 1). Nine of the isolates were described as either SVCV or PFRV when initially characterised using serological methods (Vestergård Jorgensen et al. 1989). Isolate 9695589 is a PFRV-like virus isolated from tench. All 10 viruses were obtained from N. J. Olesen of the Danish Veterinary Institute, Aarhus. Fifteen of the remaining isolates were assigned to the fish vesiculo-type virus Genogroups Ia to $\mathrm{d}$ and II to IV by others (Stone et al. 2003, Dikkeboom et al. 2004), and 5 were assigned to a genogroup using a combination of hybridisation and sequence analysis as part of this current study.

Of the isolates previously described as SVCV by Vestergård Jorgensen et al. (1989), all were assigned to Genogroup I Subgroup d by reverse hybridisation, and none of the isolates previously described as PFRV were identified as SVCV (Table 2). Of the putative PFRV isolates, none were assigned to the same group as the PFRV reference strain (Genogroup III). Instead, 2 of the putative PFRV isolates, hecht and 14241/6, were placed in Genogroup II, and the other 4 isolates were assigned to the TenRV group (Genogroup IV). Occasionally some weak cross-hybridisation was seen between probes; nonetheless, the results were unambiguous and it was possible to assign all 26 isolates into 1 of the 4 genogroups and, where appropriate, into a subgroup of Genogroup I (Fig. 1).

Genotyping of the virus isolates using reverse hybridisation was confirmed by sequence analysis. For those isolates in which the partial G-gene sequences were not available in EMBL or GenBank, amplification and sequencing was undertaken using the method described previously (Stone et al. 2003). Multiple alignments of the partial glycoprotein gene sequences were performed using Clustal W, and phylogenetic analyses were conducted using MEGA Version 3.1 (Kumar et al. 2004).

Neighbor-joining analysis revealed 4 distinct genogroups (Groups I to IV), and within Genogroup I there were 4 divisions that were supported by bootstrap values $>76 \%$ (Fig. 2, Table 2). The topology of the phylogenetic tree was similar to the trees presented by Stone et al. (2003) and Dikkeboom et al. (2004). In all cases, the sequence analysis confirmed the results 


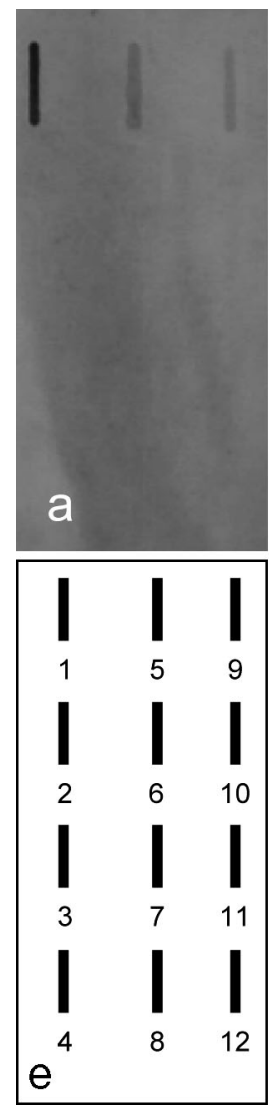

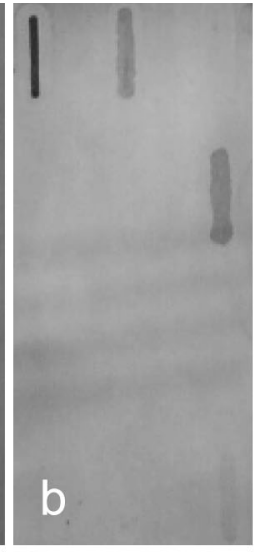
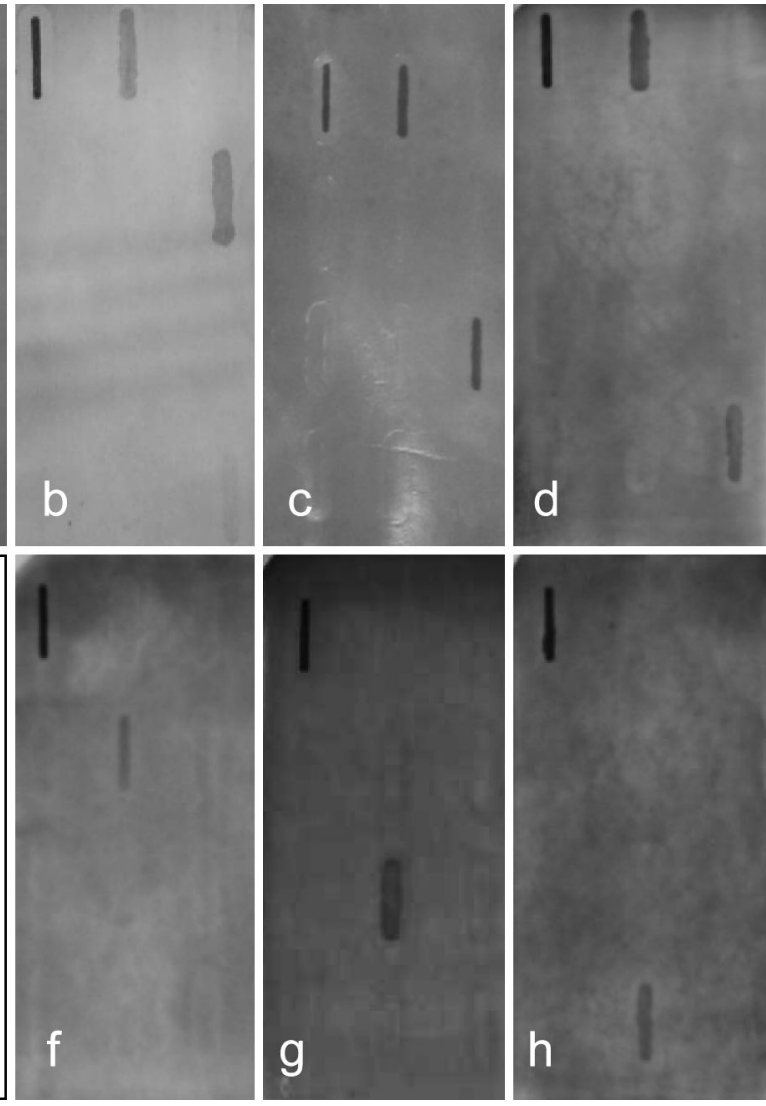

obtained using the reverse hybridisation assay (Table 2).

The sensitivity of the semi-nested PCR using the SVCV primer set was determined by experiments in which carp tissue samples were spiked with a dilution series of either the SVCV or TenRV reference strain. When applying a single round of amplification using the primers SVCV R2 and SVCV F1, no SVCV-specific signal was generated even when using $10^{5}$ plaqueforming units (pfu) $\mathrm{mg}^{-1}$ spiked tissue (Fig. 3). Following a second round of amplification using SVCV R4 and

Fig. 1. Typical reverse hybridisation patterns for viruses of (a to d) Genogroups Ia to d, respectively, (f) Genogroup II, (g) Genogroup III and (h) Genogroup IV. (e) Schematic showing the position of capture probes on the membrane: (1) DIG (digoxigenin)labelled control, (2 to 4) blanks, (5) SVCV probe (mix of Genogroup Ia to d probes), (6) GrcRV probe (Genogroup II), (7) PFRV probe (Genogroup III), (8) TenRV probe (Genogroup IV), (9) Subgroup Ia probe, (10) Subgroup Ib probe, (11) Subgroup Ic probe, and (12) Subgroup Id probe

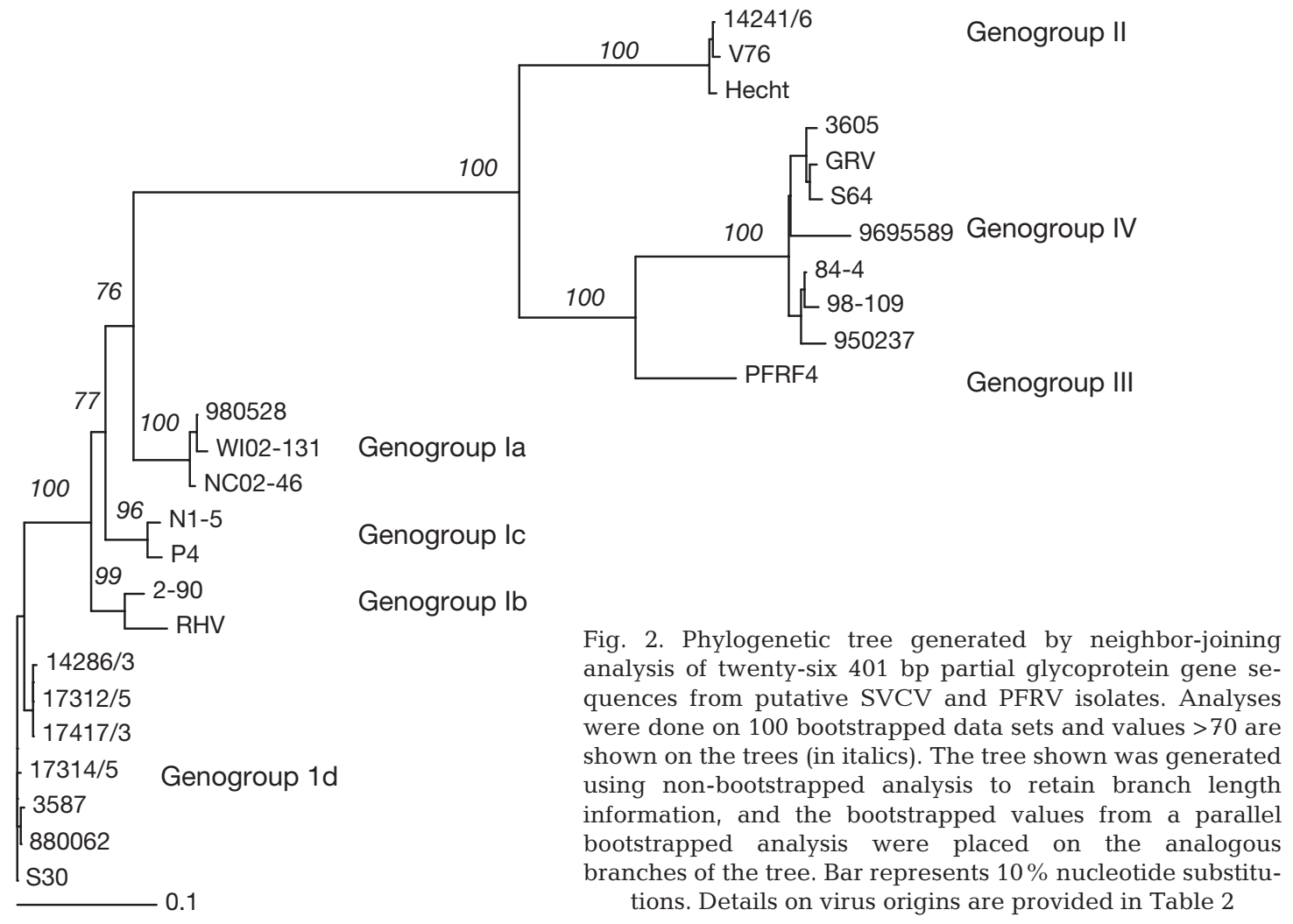


Table 2. Rhabdovirus isolates included in the studies. nd: no data; RH: reverse hybridisation

\begin{tabular}{|c|c|c|c|c|c|}
\hline Isolate identifier & Host name & $\begin{array}{l}\text { Year of } \\
\text { isolation }\end{array}$ & $\begin{array}{l}\text { Country of isolation } \\
\text { (Source) }\end{array}$ & $\begin{array}{l}\text { Initial } \\
\text { ident. }^{a}\end{array}$ & $\begin{array}{l}\text { Ident. } \\
\text { by } \mathrm{RH}^{\mathrm{b}}\end{array}$ \\
\hline S 30 & Common carp & 1971 & Yugoslavia (Fijan et al. 1971) & Id & Id \\
\hline $2 / 90$ & $\begin{array}{l}\text { Common carp } \\
\text { (Cyprinus carpio) }\end{array}$ & 1990 & Moldova & $\mathrm{Ib}$ & $\mathrm{Ib}$ \\
\hline $84 / 4$ & Brown trout (Salmo trutta) & 1984 & $\begin{array}{l}\text { UK (N. Ireland) (Adair \& } \\
\text { McLoughlin 1986) }\end{array}$ & IV & IV \\
\hline 880062 & Common carp & 1988 & UK (Stone et al. 2003) & Id & Id \\
\hline 950237 & Tench & 1995 & UK (Stone et al. 2003) & IV & IV \\
\hline 98-109 & Bream & 1998 & UK (N. Ireland) (Rowley et al. 2001) & IV & IV \\
\hline 9805281.1 & Koi carp (Cyprinus carpio) & 1998 & UK (Stone et al. 2003) & Ia & Ia \\
\hline N1-5 & $\begin{array}{l}\text { Bighead carp } \\
\text { (Aristichthys nobilis) }\end{array}$ & 1986 & Ukraine & Ic & Ic \\
\hline P4 & Common carp & 1983 & Russia & Ic & Ic \\
\hline PFRV F4 & Pike (Exos lucius) & 1973 & France (de Kinkelin et al. 1973) & III & III \\
\hline RHV & $\begin{array}{l}\text { Rainbow trout } \\
\text { (Oncorhynchus mykiss) }\end{array}$ & 1989 & Ukraine & $\mathrm{Ib}$ & $\mathrm{Ib}$ \\
\hline S 64 & Tench & 1982 & Germany (Ahne et al. 1982) & IV & IV \\
\hline V 76 & Grass carp & 1982 & Germany (Ahne et al. 1982) & II & II \\
\hline $17314 / 5$ & Common carp & nd & Hungary & SVCV & Id (Id) \\
\hline $17312 / 5$ & Common carp & nd & Hungary & SVCV & Id (Id) \\
\hline $14286 / 3$ & Sheatfish (Siluris glanis) & nd & Hungary (Fijan et al. 1984) & SVCV & Id Id) \\
\hline $17417 / 3$ & Sheatfish & 1981 & Hungary & SVCV & Id (Id) \\
\hline 3587 & Goldfish (Carrasius auratus) & nd & $\begin{array}{l}\text { nd (Vestergård Jorgensen et } \\
\text { al. 1989) }\end{array}$ & SVCV & Id (Id) \\
\hline Hecht & Pike & nd & $\begin{array}{l}\text { nd (Vestergård Jorgensen et } \\
\text { al. 1989) }\end{array}$ & PFRV & II (II) \\
\hline 3605 & Grass carp & nd & $\begin{array}{l}\text { nd (Vestergård Jorgensen et } \\
\text { al. 1989) }\end{array}$ & PFRV & II (II) \\
\hline GRV & Grass carp & nd & $\begin{array}{l}\text { nd (J Vestergård Jorgensen et } \\
\text { al. 1989) }\end{array}$ & PFRV & IV (IV) \\
\hline $14241 / 6$ & Sheatfish & nd & $\begin{array}{l}\text { nd (Vestergård Jorgensen et } \\
\text { al. 1989) }\end{array}$ & PFRV & II (II) \\
\hline WI02-131 & Common carp & 2002 & US (Dikkeboom et al. 2004) & Ia & Ia \\
\hline NC02-46 & Common carp & 2002 & US (Dikkeboom et al. 2004) & Ia & Ia \\
\hline 9695589 & Tench & nd & Belgium & PFRV & IV (IV) \\
\hline
\end{tabular}

SVCV F1, virus-specific signals were observed for both the SVCV and TenRV. The detection limit for SVCV in the semi-nested PCR assay was $10 \mathrm{pfu}$, and for TenRV the detection limit was reduced to $10^{3} \mathrm{pfu}$ $\mathrm{mg}^{-1}$ tissue (Fig. 3). The primers were designed using the published nucleotide sequence for the reference strain of SVCV, and therefore a difference in the sensitivity of the assay for the 2 viruses is not unexpected. Importantly, however, it instils increased confidence that the primer sets will have the capacity to detect the full range of highly divergent SVCV isolates.

In summary, we described a sensitive SVCV RT-PCR assay based on degenerative primer sets that lends itself to the effective detection of a genetically diverse group of viruses showing up to $17.3 \%$ nucleotide sequence divergence (Stone et al. 2003). Identification and discrimination of the SVCV-specific amplicons from products generated from the closely related TenRV were achieved using a simple reverse hybridisation approach that can be performed in $<6 \mathrm{~h}$. The hybridisation assay described is currently proposed as a means of discriminating between viruses grown in culture; however, given the sensitivity of the RT-PCR assay (10 pfu $\mathrm{ug}^{-1}$ fish tissue), it may also be possible to detect and discriminate between SVCV viruses and related viruses present at lower titres in asymptomatic carrier fish. 

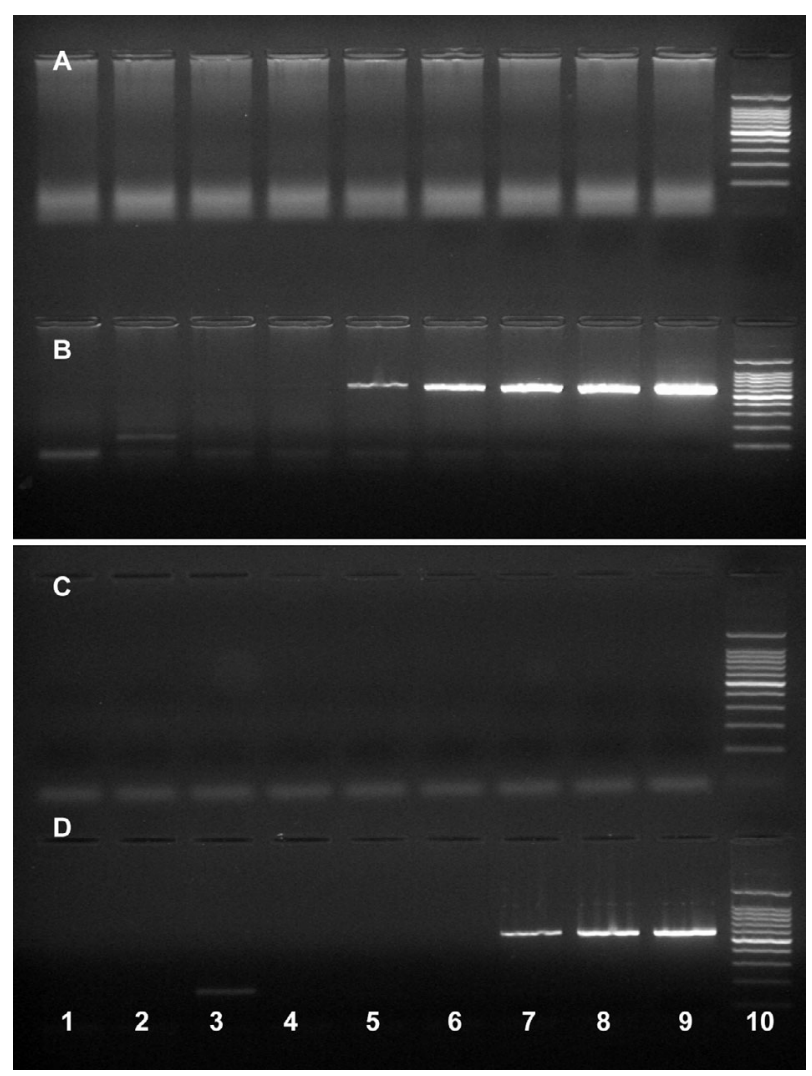

Fig. 3. Sensitivity of RT-PCR (reverse transcription polymerase chain reaction) and semi-nested PCR for $(\mathrm{A}, \mathrm{B}) \mathrm{SVCV}$ and $(C, D)$ TenRV. $(A, C)$ RT-PCR was performed using RNA extracted from $1 \mathrm{mg}$ fish tissue spiked with serially diluted virus using SVCV R2 and SVCV F1 primers (Stone et al. 2003), and (B,D) the semi-nested PCR was performed using SVCV R4 and SVCV F1 with the R2/F1 product as a template. 1: negative control; 2 : no virus; 3 : 0.1 pfu (plaque-forming units); 4: 1 pfu; 5: 10 pfu; 6: $10^{2}$ pfu; $7: 10^{3}$ pfu; $8: 10^{4}$ pfu; 9: $10^{5} \mathrm{pfu}$ 10: $100 \mathrm{bp}$ marker

Acknowledgements. We thank N. J. Olesen, W. Ahne and I. S. Shchelkunov for kindly providing their virus isolates. This work was conducted under Defra Contract F1152. The EMBL accession numbers for the sequences generated in this study are AM503904 to AM503913.

\section{LITERATURE CITED}

Adair BM, McLoughlin M (1986) Isolation of pike fry rhabdovirus from brown trout (Salmo trutta). Bull Eur Assoc Fish Pathol 6:85-86

Ahne W, Mahnel H, Steinhagen P (1982) Isolation of pike fry rhabdovirus from tench, Tinca tinca L., and white bream, Blicca bjoerkna (L.). J Fish Dis 5:535-537

Ahne W, Kurath G, Winton J (1998) A ribonuclease protection

Editorial responsibility: Catherine Collins, Aberdeen, UK assay can distinguish spring viraemia of carp virus from pike fry rhabdovirus. Bull Eur Assoc Fish Pathol 18: 220-224

De Kinkelin P, Galimard B, Bootsma R (1973) Isolation and identification of the causative agent of 'red disease' of pike (Esox lucius L., 1766). Nature 241:465-467

Dikkeboom A, Radi C, Toohey Kurth K, Marcquenski S and 5 others (2004) First report of spring viremia of carp virus in wild North American common carp (Cyprinus carpio) from Cedar Lake, Wisconsin. J Aquat Health 16:169-178

Dixon PD, Longshaw CB (2005) Assessment of commercial test kits to identify spring viraemia of carp virus. Dis Aquat Org 67:25-29

Fijan N, Petrinec Z, Sulimanovic D, Zwillenberg LO (1971) Isolation of the viral causative agent from the acute form of infectious dropsy of carp. Vet Arch 41:125-138

Fijan N, Matasin Z, Jeney Z, Oláh J, Zwillenberg LO (1984) Isolation of Rhabdovirus carpio from sheatfish (Silurus glanis) fry. In: Olah J (ed) Fish, pathogens and environment in European polyculture. Akadémiai Kiadó, Budapest, $\mathrm{p} 17-24$

Koutná M, Veselý T, Pšikal I, Hůlová J (2003) Identification of spring viraemia of carp virus (SVCV) by combined RTPCR and nested PCR. Dis Aquat Org 55:229-235

Kumar S, Tamura K, Nei M (2004) MEGA3: integrated software for molecular evolutionary genetics analysis and sequence alignment. Brief Bioinform 5:150-163

Oreshkova SF, Shchelkunov IS, Tikunova NV, Shchelkunova TI, Puzyrev AT, Ilyichev AA (1999) Detection of spring viraemia of carp virus isolates by hybridization with nonradioactive probes and amplification by polymerase chain reaction. Virus Res 63:3-10

Rowley H, Graham DA, Campbell S, Way K, Stone DM, Curran WL, Bryson DG (2001) Isolation and characterisation of rhabdovirus from wild common bream Abramis brama and roach Rutilis rutilis, farmed brown trout Salmo trutta and rainbow trout Oncorhynchus mykiss in Northern Ireland. Dis Aquat Org 48:7-15

Stone DM, Sheppard A, Lui CTY, Taylor GR, Denham K, Dixon PF, Way K (2003) Nucleotide sequence analysis of the glycoprotein gene of putative spring viraemia of carp virus and fry rhabdovirus isolates reveals four distinct piscine vesiculovirus groups. Dis Aquat Org 53:203-210

Strømmen HK, Stone DM (1998) Detection of viral haemorrhagic septicaemia virus (VHS) in fish tissues by seminested polymerase chain reaction (PCR). In: Barnes $A$, Davidson G, Hiney M, McIntosh D (eds) Proceedings of the symposium on methodology in fish disease research. Fisheries Research Services, Aberdeen, p 203-209

Thiery R, Arnauld C, Delsert C (1999) Two isolates of sea bass, Dicentrarchus labrax L, nervous necrosis virus with distinct genomes. J Fish Dis 22:201-207

Vestergård Jorgensen PE, Olesen NJ, Ahne W, Lorenzen N (1989) SVCV and PFR viruses: serological examination of 22 isolates indicates close relationship between the two fish rhabdoviruses. In: Ahne W, Kurstak E (eds) Viruses of lower vertebrates. Springer-Verlag, Berlin, p 349-366

Way K, Bark SJ, Longshaw CB, Denham KL and 8 others (2003) Isolation of a rhabdovirus during outbreaks of disease in cyprinid fish species at fishery sites in England. Dis Aquat Org 57(1/2):43-50

Submitted: January 18, 2007; Accepted: April 5, 2007

Proofs received from author(s): June 11, 2007 